\title{
Interference of Urochloa decumbens and Panicum maximum in the initial growth of six clones of Eucalyptus urograndis
}

\author{
Michel Anderson Almeida Colmanetti ${ }^{1}$, Allan Lopes Bacha ${ }^{2}$, Andreísa Flores Braga ${ }^{2}$, Pedro Luis \\ da Costa Aguiar Alves ${ }^{2 *}$, Rinaldo César de Paula ${ }^{3}$
}

${ }^{1}$ Universidade de São Paulo. Escola Superior de Agricultura “Luiz de Queiroz". Avenida Pádua Dias, 11. 13418-900 Piracicaba - SP, Brazil

${ }^{2}$ Universidade Estadual Paulista "Júlio de Mesquita Filho", Departamento de Biologia Aplicada à

Agropecuária. Via de Acesso Prof. Paulo Donato Castellane, s/n Rural. 14884900 Jaboticabal - SP, Brazil

${ }^{3}$ Universidade Estadual Paulista "Júlio de Mesquita Filho", Departamento de Produção Vegetal. Via de Acesso Prof. Paulo Donato Castellane, s/n Rural. 14884900 Jaboticabal - SP, Brazil

\section{*Corresponding author: plalves@fcav.unesp.br}

\begin{abstract}
Weeds play a strong pressure on the eucalyptus early growth, leading to a delay in their development. Therefore, many studies have tried to identify eucalyptus clones that are more tolerant to weed competition to supply information to producers, genetic improvement programs and the scientific community. The objective of this study was evaluate the interference of signal grass (Urochloa decumbens) and guinea grass (Panicum maximum) in the early growth of six clones of Eucalyptus urograndis, as well as the reciprocal effect. The experiment was conducted in an open and semi-controlled area in 8-L pots using a completely randomized experimental design with a $3 \times 6$ factorial scheme ( $U$. decumbens, $P$. maximum and weed-free control and six eucalyptus clones). After ninety days of planting, the following variables were measured: eucalyptus stem diameter, height, total chlorophyll concentration, chlorophyll fluorescence (Fv/Fm), net assimilation rate and eucalyptus and weed dry biomass. In coexistence with Guinea grass (Panicum maximum), clone 3 (ms $709 \mathrm{H}$ ) exhibited a $78.2 \%$ reduction in dry biomass compared to clone $4(\mathrm{C} 219 \mathrm{H})$, which obtained the highest dry biomass. In coexistence with signal grass (Urochloa decumbens), clone $6(\mathrm{~ms} 686 \mathrm{H})$ was the most negatively affected by weed competition, with an $80.7 \%$ lower dry biomass than clone 4 . In general, clones $1(\mathrm{~ms} 710 \mathrm{H}), 2(\mathrm{H} \mathrm{1069)}$ and 4 were more resistant, and clones 3 and 6 were more sensitive to weed interference. Both weeds were affected by eucalyptus, but Guinea grass was more sensitive than signal grass.
\end{abstract}

Keywords: Competition; eucalyptus; Guinea grass; signal grass; weed management.

Abbreviations: DAP_Days after planting; BRADC_Urochloa decumbens; PANMA_Panicum maximum; Chl_Total chlorophyll concentration; $A \_$Net assimilation rate; $E \_$Transpiration rate; Diam_Stem diameter; Fv/Fm_Chlorophyll $a$ fluorescence

\section{Introduction}

Eucalyptus is the most important forest crop in Brazil, accounting for $72 \%$ of planted forests and occupying more than 5.6 million hectares (Ibá, 2016). It is observed an annual yield increases in planted areas due to the success of genetic improvement programs and optimization of cultivation techniques, including weed control (Stape et al., 2004; Pereira et al., 2012).

The Eucalyptus urophylla $\times$ Eucalyptus grandis hybrid, Eucalyptus urograndis or simply "urograndis", combines disease and drought resistance and exhibits fast growth (Retief and Stanger, 2009), making it one of the most important species in Brazilian forestry. $E$. urograndis is the main material developed and planted in Brazil, and several commercial clones of this hybrid are available.

On the other side, the weed interference is one of the most important factors compromising forest productivity in eucalyptus plantations worldwide and has been studied over the past few decades (Sands and Nambiar, 1984; Ellis et al., 1985; Caldwell et al., 1995; Adams et al.,
2003; Schaller et al., 2003; Coll et al., 2004; Garau et al., 2008; Cruz et al., 2010; Marques et al., 2015; Bacha et al., 2016). In addition to competing with crops for light, water and nutrients, the weed community also releases allelopathic compounds into the environment, which may interfere in eucalyptus growth (Pitelli, 1987; Brendolan et al., 2000; Toledo et al., 2001; Watt et al., 2003). Furthermore, weeds may indirectly interfere in crops by serving as intermediate hosts for pests and pathogens, sheltering venomous animals, making crop practices difficult and increasing fire risk (Pitelli, 1987; Pitelli and Marchi, 1991).

Species such as Urochloa decumbens (Stapf) R.D.Webster (syn. Brachiaria decumbens Stapf) and Panicum maximum (Jacq.) are commonly observed on eucalyptus plantations, since eucalyptus cultivation has been expanding into areas previously used for pasture. These weed species have some characteristics that make their control difficult, such as: fast growth, seed dormancy and regrowth, even after herbicide application, making crop establishment and management more difficult (Schreiner, 1988; Toledo et al., 2000, 2001; Cruz et al., 2010). In addition, competition with these weeds 
may have detrimental effects on several physiological characteristics in eucalyptus, such as photosynthetic rate, stomatal conductance, transpiration rate and water use efficiency (Santos et al., 2015). The first year is the critical period of interference imposed by the weeds (Pitelli and Marchi, 1991; Nambiar and Sands, 1993; Florentine and Fox, 2003; Garau et al., 2009), which lead a reduced growth of up to $40 \%$ and $52 \%$ in stem diameter and height, respectively (Adams et al., 2003).

Since the clones have different response to weed interference during early growth (Cruz et al., 2010; Pereira et al., 2013; Graat et al., 2015), evaluate the performance of previously existing and promising clones of E. urograndis, during early growth, and with interference by $U$. decumbens and $P$. maximum, may provide information and support for genetic improvement programs. In this way, we aim to evaluate the interference of $U$. decumbens and $P$. maximum on the early development of six clones of $E$. urograndis ( $E$. urophylla $x$ E. grandis) as well as the reciprocal effect.

\section{Results}

\section{BRADC and PANMA effects on eucalyptus}

Significant interactions between factors were observed for: eucalyptus height, stem diameter, net assimilation rate, chlorophyll concentration and dry biomass, after 90 day of planted (Table 1). Significant differences in chlorophyll concentration (5.6\% decrease), dry biomass (36.8\% and $26.7 \%$ decreases with Guinea grass and signal grass, respectively) and height $(6.83 \%$ decrease with signal grass) between the treatments with and without weed coexistence were observed for all clones. However, weed coexistence did not affect transpiration rates, $\mathrm{Fv} / \mathrm{Fm}$ values, net assimilation rates or the stem diameters of eucalyptus plants.

In addition, significant differences between different eucalyptus clones were observed for stem diameter, plant height, chlorophyll concentration, photosynthesis rate and dry biomass, regardless of weed coexistence. There were no significant differences in $\mathrm{Fv} / \mathrm{Fm}$ and transpiration rate (Table 1)

\section{Eucalyptus height and stem diameter}

No significant differences in plant height were observed between different clones without weed coexistence (control) (Table 2). With Guinea grass coexistence, clone 4 achieved a higher plant height than clones 3, 2 and 6 but was not significantly different from the plant heights of clones 1 and 5. With signal grass coexistence, clone 6 achieved a plant height $24.4 \%$ lower than clone 4 , and the remaining clones achieved intermediate, but not significantly different, plant heights.

Without weed competition (control), stem diameters exhibited the same pattern observed for plant heights; clone 4 achieved a $46.7 \%$ larger stem diameter than clone 3 , and the remaining clones achieved intermediate stem diameters (Table 3). With Guinea grass coexistence, clone 3 achieved a lower stem diameter than clones 1,4 and 5. With signal grass coexistence, clone 3 again achieved a significantly lower stem diameter than clones 1,2 and 4, and the stem diameter of clone 4 was significantly different from that of clone 6 ; clone 6 was not significantly different from any of the remaining clones. No significant differences were observed between weed coexistence treatments for each clone (Table 3).
Eucalyptus net assimilation rate and total chlorophyll concentration

No differences in net assimilation rates were observed between clones without weed competition or in the presence of signal grass (Table 4). With Guinea grass coexistence, clone 2 exhibited a significantly higher net assimilation rate than clone 1 . The remaining clones exhibited intermediate net assimilation rates and were not significantly different from one another. No significant differences were observed between different coexistence treatments for each clone (Table 4).

For chlorophyll concentration, the same response pattern was observed for plants grown without competition (control) and with Guinea grass. Clone 4 exhibited a higher chlorophyll concentration than clones 3 and 6, whose chlorophyll concentrations were not significantly different from that of the remaining clones (Table 5). With signal grass, the chlorophyll concentration of clone 4 was higher than the concentrations in clones 3, 5 and 6 . In addition, clone 2 was also better than clone 5 , which had the lowest chlorophyll concentration.

Only clone 5 was sensitive to competition with signal grass; its chlorophyll concentration was $14.7 \%$ lower in the presence of signal grass than without weed coexistence (Table 5).

\section{Eucalyptus dry biomass}

The clones 3 and 6 with no coexistence had significantly lower dry biomass than the others clones (Table 6). Clone 1 exhibited the highest dry biomass, which was significantly different from clone 5 but not from clones 2 and 4. With Guinea grass coexistence, clones 3 and 6 were the most affected by weed interference, exhibiting the lowest dry biomass with decreases of $78.2 \%$ and $64.8 \%$, respectively, relative to clone 4 , which had the highest dry biomass. With signal grass coexistence, clones 1,2 and 4 exhibited significantly higher dry biomass than clones 3, 5 and 6. Clone 6 had an $80.7 \%$ lower dry biomass than clone 4 , which exhibited the highest.

Concerning the effects of weed coexistence on each clone, clone 1 had a significantly lower dry biomass in the presence of Guinea grass than without weed coexistence ( $45.4 \%$ decrease) or with signal grass $(25.3 \%$ decrease) (Table 6). Clone 5 only had a significant decrease in dry biomass in coexistence with signal grass, which was $74.2 \%$ lower than the control. Clone 6 had a significantly lower dry biomass with either weed than weed-free, and there were no significant differences in dry biomass between the two weed coexistence treatments. Relative to the control, the dry biomass decrease was $42.6 \%$ and $63.1 \%$ for treatments with Guinea grass and signal grass, respectively (Table 6).

\section{Eucalyptus interfering on BRADC and PANMA growth}

Regarding the opposite effect, i.e., the interference of eucalyptus clones on weed growth, only clones 1 and 4 interfered on the signal grass growth at $90 \mathrm{DAP}$, resulting in dry biomass decreases of $58.7 \%$ and $57.4 \%$, respectively, when compared to the control (Table 7). Only clones 1, 2 and 4 resulted in significant dry biomass decreases in Guinea grass $(71.2 \%, 58.7 \%$ and $76.9 \%$ 
Table 1. Effect of two weed species on six clones of eucalyptus after 90 days of coexistence.

\begin{tabular}{|c|c|c|c|c|c|c|c|}
\hline Factor & Height $(\mathrm{cm})$ & Diam $(\mathrm{mm})$ & $\mathrm{Fv} / \mathrm{Fm}$ & Chl (RU) & $A\left(\mu \mathrm{mol} \mathrm{CO}{ }_{2} \mathrm{~m}^{-2} \mathrm{~s}^{-2}\right)$ & $E\left(\mathrm{mmol} \mathrm{H}_{2} \mathrm{O} \mathrm{m}^{-2} \mathrm{~s}^{-2}\right)$ & Dry biomass $(\mathrm{g})$ \\
\hline \multicolumn{8}{|c|}{ COEXISTENCE } \\
\hline CONTROL & $39.5 \mathrm{~A}$ & $5.4 \mathrm{~A}$ & $0.780 \mathrm{~A}$ & $41.0 \mathrm{~A}$ & $10.9 \mathrm{~A}$ & $40.1 \mathrm{~A}$ & $37.4 \mathrm{~A}$ \\
\hline PANMA & $37.1 \mathrm{AB}$ & $4.9 \mathrm{~A}$ & $0.761 \mathrm{~A}$ & $38.7 \mathrm{~B}$ & $13.2 \mathrm{~A}$ & $36.9 \mathrm{~A}$ & $23.6 \mathrm{~B}$ \\
\hline BRADC & $36.8 \mathrm{~B}$ & $4.9 \mathrm{~A}$ & $0.775 \mathrm{~A}$ & $38.7 \mathrm{~B}$ & $11.4 \mathrm{~A}$ & $38.9 \mathrm{~A}$ & $27.4 \mathrm{~B}$ \\
\hline \multicolumn{8}{|l|}{ CLONE } \\
\hline (1) $\mathrm{ms} 710 \mathrm{H}$ & $38.2 \mathrm{~B}$ & $5.5 \mathrm{AB}$ & $0.782 \mathrm{~A}$ & $39.8 \mathrm{BC}$ & $9.9 \mathrm{~B}$ & $29.6 \mathrm{~A}$ & $43.4 \mathrm{~A}$ \\
\hline (2) H 1069 & $37.2 \mathrm{~B}$ & $5.1 \mathrm{AB}$ & $0.780 \mathrm{~A}$ & $41.7 \mathrm{AB}$ & $14.6 \mathrm{~A}$ & $48.8 \mathrm{~A}$ & $35.6 \mathrm{AB}$ \\
\hline (3) $\mathrm{ms} 709 \mathrm{H}$ & $33.6 \mathrm{C}$ & $3.9 \mathrm{C}$ & $0.764 \mathrm{~A}$ & $36.0 \mathrm{D}$ & $12.3 \mathrm{AB}$ & $44.1 \mathrm{~A}$ & $13.8 \mathrm{C}$ \\
\hline (4) $\mathrm{C} 219 \mathrm{H}$ & $42.4 \mathrm{~A}$ & $5.8 \mathrm{~A}$ & $0.780 \mathrm{~A}$ & $44.2 \mathrm{~A}$ & $11.4 \mathrm{AB}$ & $35.1 \mathrm{~A}$ & $43.5 \mathrm{~A}$ \\
\hline (5) $\mathrm{ms} 703 \mathrm{H}$ & $40.4 \mathrm{~A}$ & $5.0 \mathrm{AB}$ & $0.754 \mathrm{~A}$ & $38.7 \mathrm{BCD}$ & $12.9 \mathrm{AB}$ & $41.8 \mathrm{~A}$ & $27.9 \mathrm{~B}$ \\
\hline (6) $\mathrm{ms} 686 \mathrm{H}$ & $34.8 \mathrm{C}$ & $4.4 \mathrm{BC}$ & $0.770 \mathrm{~A}$ & $36.7 \mathrm{CD}$ & $9.8 \mathrm{~B}$ & $32.3 \mathrm{~A}$ & $16.3 \mathrm{C}$ \\
\hline $\mathrm{F}$ & $3.78^{* * *}$ & $3.5 * *$ & $1.02^{\text {ns }}$ & $4.85 * *$ & $2.97 * *$ & $1.79^{\mathrm{ns}}$ & $16.50^{* * *}$ \\
\hline P-value & $<0.001$ & $<0.001$ & 0.4282 & $<0.0001$ & 0.01 & 0.12 & $<0.0001$ \\
\hline
\end{tabular}

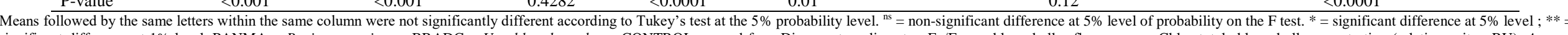

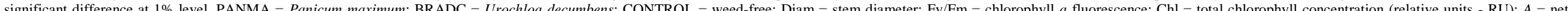
assimilation rate; $E=$ transpiration rate. Clone $1=\mathrm{ms} 710 \mathrm{H}$; Clone 2 $=\mathrm{H}$ 1069; Clone $3=\mathrm{ms} 709 \mathrm{H} ;$ Clone $4=\mathrm{C} 219 \mathrm{H}$; Clone $5=\mathrm{ms} 703 \mathrm{H}$; Clone $6=\mathrm{ms} 686 \mathrm{H}$

Table 2. Interference of two weed species on height $(\mathrm{cm})$ of six eucalyptus clones at 90 days after planting

\begin{tabular}{|c|c|c|c|c|c|c|c|c|}
\hline \multirow[b]{2}{*}{ Coexistence } & \multicolumn{8}{|l|}{ CLONE } \\
\hline & $(1)$ & (2) & (3) & (4) & (5) & (6) & F & P-value \\
\hline CONTROL & $40.9 \mathrm{~A} \mathrm{a}$ & $37.0 \mathrm{~A} \mathrm{a}$ & $35.7 \mathrm{~A} \mathrm{a}$ & $42.5 \mathrm{~A} \mathrm{a}$ & $42.1 \mathrm{~A} \mathrm{a}$ & $38.0 \mathrm{~A} \mathrm{a}$ & $1.45^{\mathrm{ns}}$ & 0.19 \\
\hline PANMA & $36.6 \mathrm{~A} \mathrm{abc}$ & $35.3 \mathrm{~A} \mathrm{bc}$ & $31.4 \mathrm{Ac}$ & $42.9 \mathrm{~A} \mathrm{a}$ & $41.4 \mathrm{~A} \mathrm{ab}$ & $34.8 \mathrm{~A} \mathrm{bc}$ & $4.87 * *$ & $<0.001$ \\
\hline BRADC & $37.5 \mathrm{~A} \mathrm{ab}$ & $38.7 \mathrm{~A} \mathrm{ab}$ & $33.8 \mathrm{~A} \mathrm{ab}$ & $41.8 \mathrm{~A} \mathrm{a}$ & $37.5 \mathrm{~A} \mathrm{ab}$ & $31.6 \mathrm{Ab}$ & $2.44 *$ & 0.0237 \\
\hline $\mathrm{F}$ & $0.91^{\text {ns }}$ & $0.80^{\text {ns }}$ & $1.20^{\text {ns }}$ & $0.41^{\mathrm{ns}}$ & $1.79^{\text {ns }}$ & $1.90^{\text {ns }}$ & ---- & ---- \\
\hline P-value & 0.47 & 0.53 & 0.32 & 0.8 & 0.15 & 0.12 & ----- & ------ \\
\hline
\end{tabular}

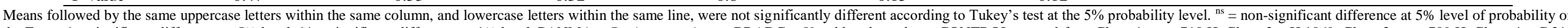

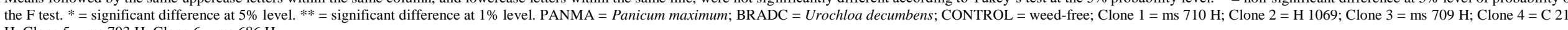
$\mathrm{H} ;$ Clone $5=\mathrm{ms} 703 \mathrm{H} ;$ Clone $6=\mathrm{ms} 686 \mathrm{H}$.

Table 3. Interference of two weed species on stem diameter $(\mathrm{mm})$ of six eucalyptus clones at 90 days after planting.

\begin{tabular}{|c|c|c|c|c|c|c|c|c|}
\hline \multirow[b]{2}{*}{ Coexistence } & \multicolumn{8}{|l|}{ CLONE } \\
\hline & (1) & (2) & (3) & (4) & (5) & (6) & $\mathrm{F}$ & P-value \\
\hline CONTROL & $54.7 \mathrm{~A} \mathrm{ab}$ & $50.3 \mathrm{~A} \mathrm{ab}$ & $39.4 \mathrm{~A} \mathrm{~b}$ & $57.8 \mathrm{~A} \mathrm{a}$ & $51.8 \mathrm{~A} \mathrm{ab}$ & $48.6 \mathrm{~A} \mathrm{ab}$ & $2.22^{*}$ & 0.038 \\
\hline PANMA & $54.9 \mathrm{~A} \mathrm{a}$ & $49.6 \mathrm{~A} \mathrm{ab}$ & $38.5 \mathrm{~A} \mathrm{~b}$ & $57.2 \mathrm{~A} \mathrm{a}$ & $51.3 \mathrm{~A} \mathrm{a}$ & $44.2 \mathrm{~A} \mathrm{ab}$ & $3.37 * *$ & 0.003 \\
\hline BRADC & $55.4 \mathrm{~A} \mathrm{ab}$ & $52.8 \mathrm{~A} \mathrm{ab}$ & $37.9 \mathrm{~A} \mathrm{c}$ & $59.1 \mathrm{~A} \mathrm{a}$ & 46.3 A abc & $40.3 \mathrm{~A} \mathrm{bc}$ & $3.61 * *$ & 0.001 \\
\hline $\mathrm{F}$ & $0.02^{\mathrm{ns}}$ & $0.32^{\mathrm{ns}}$ & $0.47^{\mathrm{ns}}$ & $0.06^{\mathrm{ns}}$ & $1.03^{\mathrm{ns}}$ & $0.93^{\mathrm{ns}}$ & ----- & ----- \\
\hline P-value & 0.99 & 0.86 & 0.76 & 0.99 & 0.40 & 0.45 & ----- & ---- \\
\hline
\end{tabular}

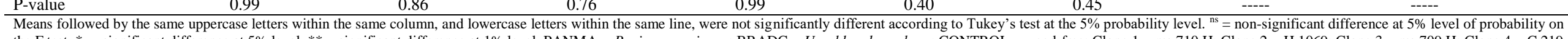

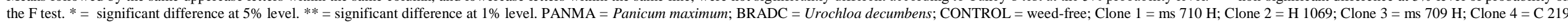
H; Clone $5=$ ms 703 H; Clone $6=$ ms $686 \mathrm{H}$ 
Table 4. Interference of two weed species on net assimilation rate $\left(\mu \mathrm{mol} \mathrm{CO} \mathrm{Cm}^{-2} \mathrm{~s}^{-2}\right)$ of six eucalyptus clones at 90 days after planting

\begin{tabular}{|c|c|c|c|c|c|c|c|c|}
\hline \multirow[b]{2}{*}{ Coexistence } & \multicolumn{8}{|l|}{ CLONE } \\
\hline & (1) & (2) & (3) & (4) & (5) & (6) & $\mathrm{F}$ & P-value \\
\hline CONTROL & $8.7 \mathrm{~A} \mathrm{a}$ & $12.7 \mathrm{~A} \mathrm{a}$ & $8.7 \mathrm{~A} \mathrm{a}$ & $10.7 \mathrm{~A} \mathrm{a}$ & $14.5 \mathrm{~A} \mathrm{a}$ & $10.4 \mathrm{~A} \mathrm{a}$ & $2.89^{\mathrm{ns}}$ & 0.13 \\
\hline PANMA & $8.5 \mathrm{Ab}$ & $20.8 \mathrm{~A} \mathrm{a}$ & 14.6 A ab & $10.9 \mathrm{~A} \mathrm{ab}$ & $13.6 \mathrm{~A} \mathrm{ab}$ & $10.4 \mathrm{~A} \mathrm{ab}$ & $4.97^{*}$ & 0.05 \\
\hline BRADC & $12.7 \mathrm{~A} \mathrm{a}$ & $10.2 \mathrm{~A} \mathrm{a}$ & $13.7 \mathrm{~A} \mathrm{a}$ & $12.6 \mathrm{~A} \mathrm{a}$ & $10.5 \mathrm{~A} \mathrm{a}$ & $8.6 \mathrm{~A} \mathrm{a}$ & $2.12^{\mathrm{ns}}$ & 0.21 \\
\hline $\mathrm{F}$ & $1.03^{\mathrm{ns}}$ & $6.18^{\mathrm{ns}}$ & $1.47^{\mathrm{ns}}$ & $0.25^{\mathrm{ns}}$ & $3.68^{\mathrm{ns}}$ & $0.90^{\mathrm{ns}}$ & ----- & ----- \\
\hline P-value & 0.53 & 0.14 & 0.43 & 0.86 & 0.22 & 0.57 & ----- & ----- \\
\hline
\end{tabular}

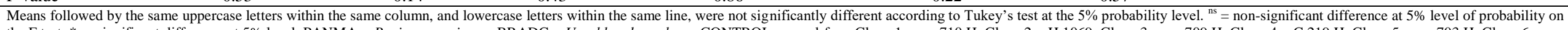

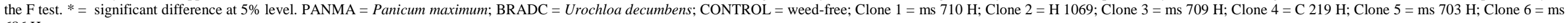

Table 5. Interference of two weed species on total chlorophyll concentration (relative units - RU) of six eucalyptus clones at 90 days after planting.

\begin{tabular}{|c|c|c|c|c|c|c|c|c|}
\hline \multirow[b]{2}{*}{ Coexistence } & \multicolumn{8}{|l|}{ CLONE } \\
\hline & (1) & (2) & (3) & (4) & (5) & (6) & $\mathrm{F}$ & P-value \\
\hline CONTROL & $41.1 \mathrm{~A} \mathrm{ab}$ & $42.5 \mathrm{~A} \mathrm{ab}$ & $36.6 \mathrm{~A} \mathrm{~b}$ & $45.3 \mathrm{~A} \mathrm{a}$ & $42.1 \mathrm{~A} \mathrm{ab}$ & $38.1 \mathrm{~A} \mathrm{~b}$ & $3.50^{* *}$ & 0.002 \\
\hline PANMA & $39.5 \mathrm{~A} \mathrm{ab}$ & $40.8 \mathrm{~A} \mathrm{ab}$ & $35.6 \mathrm{~A} \mathrm{~b}$ & $43.6 \mathrm{~A} \mathrm{a}$ & $38.2 \mathrm{AB} a b$ & $35.4 \mathrm{~A} \mathrm{~b}$ & $3.90 * *$ & 0.001 \\
\hline BRADC & $38.8 \mathrm{~A} \mathrm{abc}$ & $41.4 \mathrm{~A} \mathrm{ab}$ & $36.0 \mathrm{~A} \mathrm{bc}$ & $43.5 \mathrm{~A} \mathrm{a}$ & $35.9 \mathrm{~B} \mathrm{c}$ & $36.7 \mathrm{~A} \mathrm{bc}$ & $3.91^{* *}$ & 0.001 \\
\hline $\mathrm{F}$ & $0.79^{\mathrm{ns}}$ & $0.61^{\text {ns }}$ & $0.17^{\mathrm{ns}}$ & $0.20^{\mathrm{ns}}$ & $3.73 * *$ & $0.63^{\text {ns }}$ & ---- & ----- \\
\hline P-value & 0.54 & 0.66 & 0.95 & 0.94 & 0.009 & 0.64 & ----- & -.--- \\
\hline
\end{tabular}

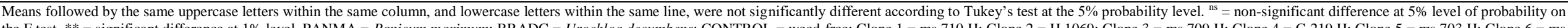

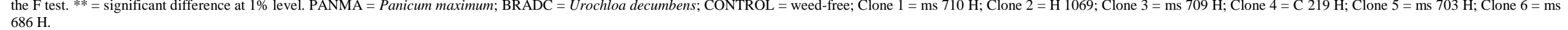

Table 6. Interference of two weed species on dry biomass (g) of six eucalyptus clones at 90 days after planting.

\begin{tabular}{|c|c|c|c|c|c|c|c|c|}
\hline \multirow[b]{2}{*}{ Coexistence } & \multicolumn{8}{|l|}{ CLONE } \\
\hline & (1) & (2) & (3) & (4) & (5) & (6) & $\mathrm{F}$ & P-value \\
\hline CONTROL & $54.8 \mathrm{~A} \mathrm{a}$ & $42.5 \mathrm{~A} \mathrm{ab}$ & $19.5 \mathrm{~A} \mathrm{c}$ & $45.9 \mathrm{~A} \mathrm{ab}$ & $37.6 \mathrm{~A} \mathrm{~b}$ & $23.9 \mathrm{Ac}$ & $17.5 * *$ & $<0.0001$ \\
\hline PANMA & $29.9 \mathrm{C}$ ab & $26.6 \mathrm{~A} \mathrm{ab}$ & $8.5 \mathrm{~A} \mathrm{~b}$ & $39.0 \mathrm{~A} \mathrm{a}$ & $28.7 \mathrm{~A} \mathrm{ab}$ & $13.7 \mathrm{~B} \mathrm{~b}$ & $6.67 * *$ & 0.01 \\
\hline BRADC & $40.9 \mathrm{~B} \mathrm{a}$ & $34.3 \mathrm{~A} \mathrm{a}$ & $13.3 \mathrm{~A} \mathrm{~b}$ & $45.6 \mathrm{~A} \mathrm{a}$ & $9.7 \mathrm{~B} \mathrm{~b}$ & $8.8 \mathrm{~B} \mathrm{~b}$ & $31.0 * *$ & $<0.0001$ \\
\hline $\mathrm{F}$ & $46.8 * *$ & $6.54^{\mathrm{ns}}$ & $3.27^{\mathrm{ns}}$ & $1.19^{\mathrm{ns}}$ & $4.91^{*}$ & $14.2^{*}$ & ----- & ----- \\
\hline P-value & 0.005 & 0.14 & 0.14 & 0.43 & 0.02 & 0.02 & ----- & ----- \\
\hline
\end{tabular}

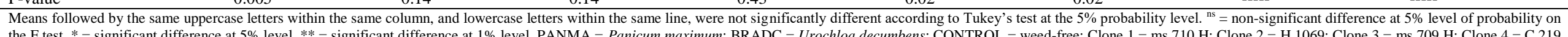

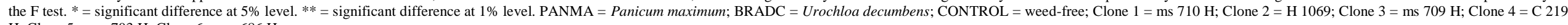
H; Clone $5=$ ms 703 H; Clone 6 = ms 686 H.

Table 7. Effect of coexistence with six eucalyptus clones on dry biomass (g) of two weed species.

\begin{tabular}{lll}
\hline Treatment & PANMA & BRADC \\
\hline CONTROL & $33.0 \mathrm{~A}$ & $40.7 \mathrm{~A}$ \\
$(3) \mathrm{ms} 709 \mathrm{H}$ & $28.3 \mathrm{~A}$ & $34.3 \mathrm{AB}$ \\
(6) $\mathrm{ms} 686 \mathrm{H}$ & $27.6 \mathrm{~A}$ & $26.3 \mathrm{AB}$ \\
$(5) \mathrm{ms} 703 \mathrm{H}$ & $23.1 \mathrm{AB}$ & $22.9 \mathrm{AB}$ \\
$(2) \mathrm{H} 1069$ & $13.6 \mathrm{BC}$ & $23.6 \mathrm{AB}$ \\
$(1) \mathrm{ms} 710 \mathrm{H}$ & $9.5 \mathrm{C}$ & $16.8 \mathrm{~B}$ \\
(4) $\mathrm{C} 219 \mathrm{H}$ & $7.6 \mathrm{C}$ & $17.3 \mathrm{~B}$ \\
\hline F & $12.1^{* *}$ & $4.94^{* *}$ \\
P-value & 0.0001 & 0.009 \\
\hline
\end{tabular}

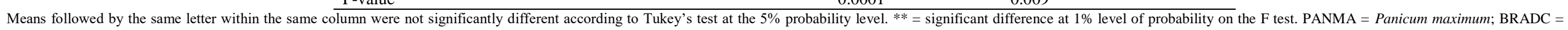

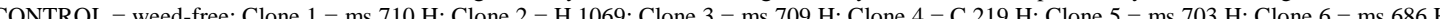


when compared to the control, respectively). Overall, both signal grass and Guinea grass exhibited lower dry biomass when grown with clones 1 and 4 .

\section{Discussion}

The weed interference observed in the present study, which had negative effects on some eucalyptus variables, such as: plant height, stem diameter, dry biomass, chlorophyll concentration and net assimilation rate (Tables 1 to 6), is in accordance with several previous studies that reported a higher sensitivity of eucalyptus plants to interference during the first year following their establishment (Adams et al., 2003; Florentine and Fox, 2003; Garau et al., 2009; Tarouco et al., 2009). Interference by weed community composed mainly of signal grass was observed to have a negative effect on Eucalyptus urophylla between 14 and 140 days, which was characterized as a critical period for weed interference (CPWI) (Toledo et al., 2000).

Weed density is also an important factor on weed interference in the early growth stages of several eucalyptus species. Reduced growth was observed for $E$. grandis from a density of $4 P$. maximum plants $\mathrm{m}^{-2}$ (Dinardo et al., 2003). Similar results were reported for interference of $U$. decumbens on $E$. grandis (Toledo et al., 2001). Bacha et al. (2016) observed that regrowth of signal grass at a density of 2.6 plants $\mathrm{m}^{-2}$ caused reduced growth in leaf area and dry biomass of E. urograndis up to $89 \%$ and $87 \%$, respectively.

Differences in responses between different clones were observed for all variables measured. The degree of weed interference on crops may be determined by several factors, such as: the weed species, density and distribution, edaphoclimatic characteristics of the region and the species/clone/cultivar used (Bleasdale, 1960; Pitelli, 1985). Thus, it is possible to observe that some clones were high sensitivity to interference imposed by weeds (clones 3 and 6), but also some of them were more tolerant, such as clones 1 and 4. Silva et al. (1997) observed that Corymbia citriodora (ex E. citriodora) was more sensitive to competition with Brachiaria brizantha than $E$. grandis. Different responses for different $E$. urograndis clones have also been reported (Cruz et al., 2010; Graat et al., 2015).

The present results indicate that clones 3 and 6, which were the most affected by weed interference, and clones 1 and 4, which grew better, exhibited different behaviors regarding resource uptake from the environment. During the first months after planting, eucalyptus plants allocate large amounts of nutrients and photoassimilates to the roots to meet their water and nutrient demands (Gonçalves et al., 2000). However, weed competition may have decreased resource availability. It is therefore likely that clones 3 and 6 were not able to maintain their normal metabolic levels, resulting in more pronounced decreases in the variables measured.

Furthermore, the high competitive capacity of grasses, which affects eucalyptus height, stem diameter and dry biomass, is due to their fast root growth. Their fast root growth enables them to better exploit environment resources and makes them very aggressive, especially during regrowth (Bacha et al., 2016), which enables rapid colonization of an area (Toledo et al., 1996).

Nitrogen is a key nutrient for chlorophyll formation, and nitrogen concentration is directly reflected in leaf chlorophyll concentration (Donahue et al., 1990). Therefore, the observed chlorophyll concentrations may be directly related to the fertilizations performed at 20 and 55 DAP. Because clones 3 and 6 probably had a lower competitive capacity (for nutrient uptake), they exhibited lower chlorophyll concentrations than clone 4 (which grew more). In addition, several studies have highlighted that the amount of chlorophylls is directly related to the photosynthetic rate and consequently, plant growth and dry biomass production (Porra et al., 1989; Chappelle and Kim, 1992; Ripullone et al., 2003). Therefore, the present results (Tables 1 to 6 ) indicate that clones 3 and 6 suffered more from weed competition, whereas clones 1 and 4 were more tolerant of weed coexistence.

In terms of the interference of eucalyptus clones on weed growth, the most resistant clones were also those that most affected weed growth. In addition, Guinea grass was more sensitive than signal grass to coexistence with eucalyptus (Table 7). It was also observed that there was interaction between eucalyptus clones and weed plants, as reported in previous studies (Cruz et al., 2010; Pereira et al., 2013), in which the rate of growth and the architecture of eucalyptus plants were different among the clones. Thus, it is possible to infer that the different heights observed in the clones, such as $31.4 \mathrm{~cm}$ for clone 3 and $42.9 \mathrm{~cm}$ for clone 4, may have influenced the growth behavior of signal grass and Guinea grass.

\section{Materials and Methods}

\section{Experimental area}

An experiment was conducted in 8-L pots in an open and semi-controlled area in the municipality of Jaboticabal, São Paulo, Brazil (595 m altitude; 2115'22" S; $48^{\circ} 18^{\prime} 58^{\prime \prime}$ W) until 90 days after eucalyptus planting (DAP). The region's climate is classified as Cwa according to the Köppen (1948) climate classification; it is subtropical and relatively dry in winter and has rainy summers, with average annual rain fall of $1225 \mathrm{~mm}$ and an average temperature $22{ }^{\circ} \mathrm{C}$. Each pot was considered an experimental plot and watered daily to field capacity.

\section{Plant materials}

Seedlings of the following eucalyptus hybrid ( $E$. urophylla $x \mathrm{E}$. grandis) clones were used: $\mathrm{ms} 710 \mathrm{H}$ (clone 1), H 1069 (clone 2), ms $709 \mathrm{H}$ (clone 3), C $219 \mathrm{H}$ (clone 4), ms $703 \mathrm{H}$ (clone 5) and ms $686 \mathrm{H}$ (clone 6). The seedlings were approximately 90 days old when they were planted with average heights of $20 \mathrm{~cm}, 10$ to 12 leaves, $1.25-\mathrm{mm}$ stem diameters and active root systems. Bifurcated seedlings were avoided.

The substrate consisted of a 2:1 soil: sand mix (v:v). The soil was collected from the surface layer of a Dark Red Latosol. After substrate preparation and planting of the seedlings, nitrogen fertilizer consisting of $50 \mathrm{~mL}$ of $1 \%$ urea (equivalent to $130 \mathrm{~kg} \mathrm{ha}^{-1}$ ) was applied at 20 DAP, and nitrogen fertilizer consisting of $50 \mathrm{~mL}$ of $2 \%$ urea $\left(260 \mathrm{~kg} \mathrm{ha}^{-1}\right)$ was applied at 55 DAP. A topdressing with 4-14-8 (NPK) fertilizer equivalent to $400 \mathrm{~kg} \mathrm{ha}^{-1}$ was also performed at $60 \mathrm{DAP}$.

Guinea grass ( $P$. maximum; PANMA) and signal grass ( $U$. decumbens; BRADC) seedlings were obtained by sowing diaspores in styrofoam cell trays containing substrate for vegetables to standardize weed size at transplantation. Weed seedlings were transplanted into pots when they presented two tillers. One weed seedling was transplanted into each pot $5 \mathrm{~cm}$ away from the eucalyptus seedling on the day of eucalyptus planting. 


\section{Treatments and experimental design}

A completely randomized experimental design was used with a $3 \times 6$ factorial scheme; the factors were the presence of guinea grass, signal grass or weed-free control and six eucalyptus clones (1, 2, 3, 4, 5 and 6), for a total of 18 treatments. Three replicates were carried out per treatment.

\section{Assessed variables}

At 90 DAP, the following variables of the eucalyptus plants were measured: plant height (measured from the base of the plant to the top with a $100-\mathrm{cm}$ wooden ruler), stem diameter (measured $2 \mathrm{~cm}$ from ground level using a digital caliper) and net assimilation rate and transpiration (on the third fully expanded leaf using an LI-6400 infrared gas analyzer (LiCor)). For the gas exchange measurements, the following settings were used: reference $\mathrm{CO}_{2}$ of $350 \mu \mathrm{mol} \mathrm{mol}{ }^{-1}$, reference $\mathrm{H}_{2} \mathrm{O}$ of 9 mmol mol ${ }^{-1}$, air temperature of $25{ }^{\circ} \mathrm{C}$ in the chamber, atmospheric pressure of $1000 \mathrm{KPa}$, flow rate of $400 \mu \mathrm{mol}$ $\mathrm{s}^{-1}$ and photosynthetically active photon flux (quantum) of $1000 \mu \mathrm{mol} \mathrm{m} \mathrm{m}^{-2} \mathrm{~s}^{-1}$. The total chlorophyll concentration (SPAD-502, Minolta) and chlorophyll $a$ fluorescence (Fv/Fm; PEA, Hansatech) were also determined on the third fully expanded leaf. Following the measurements, eucalyptus and weed plants were cut at ground level and placed in a forced air oven at $70^{\circ} \mathrm{C}$ for 96 hours for dry biomass determination.

\section{Statistical analysis}

The data were subjected to analysis of variance (ANOVA) using the F-test followed by Tukey's test at a $5 \%$ probability level. The variables were transformed to meet the assumptions of normality and homoscedasticity. All statistical analyses were performed by using SAS (Statistical Analysis System) 9.3.

\section{Conclusion}

It may therefore be concluded that clones $1(\mathrm{~ms} 710 \mathrm{H}), 2$ $(\mathrm{H} 1069)$ and $4(\mathrm{C} 219 \mathrm{H})$ were more resistant to weed interference, whereas clones $3(\mathrm{~ms} 709 \mathrm{H})$ and $6(\mathrm{~ms} 686$ $\mathrm{H})$ were more sensitive. Only clones 1 and 4 affected the growth of signal grass, and clones 1, 2 and 4 affected the growth of Guinea grass. Therefore, Guinea grass was more sensitive to coexistence with eucalyptus plants.

\section{Acknowledgement}

The authors would like to thank the FIBRIA for the clones and all of the members of the Weed Laboratory of UNESP (LAPDA) for their support in the study.

\section{References}

Adams PR, Beadle CL, Mendham NJ, Smethurst PJ (2003) The impact of timing and duration of grass control on growth of a young Eucalyptus globulus Labill plantation. New Forest. 26(2): 147-165.

Bacha AL, Pereira FCM, Pires RN, Nepomuceno MP, Alves PLCA (2016) Interference of seeding and regrowth of signal grass weed (Urochloa decumbens) during the initial development of Eucalyptus urograndis (E. grandis x E. urophylla). Aust J Crop Sci. 10(3): 322-330.
Bleasdale JKA (1960) Studies on plant competition. In: Harper JL (ed) The biology of weeds, Oxford, UK.

Brendolan RA, Pellegrini MT, Alves PLCA (2000) Efeitos da nutrição mineral na competição inter e intraespecífica de Eucalyptus grandis e Brachiaria decumbens: 1 - crescimento. Sci For. 58: 49-57.

Caldwell JM, Sucoff EI, Dixon RK (1995) Grass interference limits resource availability and reduces growth of juvenile red pine in the field. New Forest. 10(1): 1-15.

Chappelle EW, Kim MS (1992) Ratio analysis of reflectance spectra (RARS): an algorithm for the remote estimation of the concentrations of chlorophyll $\mathrm{a}$, chlorophyll b, and carotenoids in soybean leaves. Remote Sens Environ. 39(3): 239-247.

Coll L, Balandier P, Picon-Cochard C (2004) Morphological and physiological responses of beech (Fagus sylvatica) seedlings to grass-induced belowground competition. Tree Physiol. 24(1): 45-54.

Cruz MB, Alves PLCA, Karam D, Ferraudo AS (2010) Capim-colonião e seus efeitos sobre o crescimento inicial de clones de Eucalyptus $\times$ urograndis. Cienc Florest. 20(3): 391-401.

Dinardo W, Toledo REB, Alves PLCA, Pitelli RA (2003) Efeito da densidade de plantas de Panicum maximum Jacq sobre o crescimento inicial de Eucalyptus grandis W Hill ex Maiden. Sci For. 64:59-68.

Donahue RA, Berg VS, Vogelmann TC (1990) Assessment of the potential of the blue light gradient in soybean pulvini as a leaf orientation signal. Physiol Plant. 79(4): 593-598.

Ellis RC, Webb DP, Graley AM, Rout AF (1985) The effect of weed competition and nitrogen nutrition on the growth of seedlings of Eucalyptus delegatensis in a highland area of Tasmania. Aust For Res. 15(4): 395408.

Florentine SK, Fox JE (2003) Competition between Eucalyptus victrix seedlings and grass species. Ecol Res. 18(1): 25-39.

Garau AM, Ghersa CM, Lemcoff JH, Barañao JJ (2009) Weeds in Eucalyptus globulus subsp maidenii (F Muell) establishment: effects of competition on sapling growth and survivorship. New Forest. 37(3): 251-264.

Garau AM, Lemcoff JH, Ghersa CM, Beadle CL (2008) Water stress tolerance in Eucalyptus globulus Labill subsp maidenii (F Muell) saplings induced by water restrictions imposed by weeds. For Ecol Manage. 255(7): 2811-2819.

Gonçalves JDM, Stape JL, Benedetti V, Fessel VAG, Gava JL (2000) Reflexos do cultivo mínimo e intensivo do solo em sua fertilidade e na nutrição das árvores. Nutrição e fertilização florestal. IPEF. 3-57.

Graat Y, Rosa JO, Nepomuceno MP, Carvalho LB, Alves PLCA (2015) Grass weeds interfering with eucalypt: effects of the distance of coexistence on the initial plant growth. Planta Daninha. 33(2): 203-211.

Ibá (2016) Indústria brasileira de árvores. Relatório Ibá.

Köppen W (1948) Climatologia: con un estudio de los climas de la tierra. Fondo de Cultura Econômica. México.

Marques DB, Martins PDFRB, Parreira MC, Alves PLCA (2015) Companion crops upon Eucalyptus urograndis initial development. Bosque. 36(2): 163170.

Nambiar ES, Sands R (1993) Competition for water and nutrients in forests. Can J For Res. 23(10): 1955-1968.

Pereira FCM, Yamauti MS, Alves PLCA (2012) Interaction between weed management and covering 
fertilization in the initial growth of Eucalyptus grandis x E. urophylla. Rev Árvore. 36(5): 941-950.

Pereira FCM, Alves PLCA, Martins JVF (2013) Interference of grasses on the growth of eucalyptus clones. J Agric Sci. 5(11): 173.

Pitelli RA (1985) Interferência de plantas daninhas em culturas agrícolas. Inf. Agropec. 11(129): 16-27.

Pitelli RA, Marchi SR (1991) Interferência das plantas invasoras nas áreas de reflorestamento. Paper presented at the 3rd Seminário técnico sobre plantas daninhas e o uso de herbicidas em reflorestamento, Belo Horizonte, MG, Brasil, 1991.

Pitelli RA (1987) Competição e controle das plantas daninhas em áreas agrícolas. Série técnica IPEF. 4(12): $1-24$.

Porra RJ, Thompson WA, Kriedemann PE (1989) Determination of accurate extinction coefficients and simultaneous equations for assaying chlorophylls a and $b$ extracted with four different solvents: verification of the concentration of chlorophyll standards by atomic absorption spectroscopy. Biochim Biophys Acta. Bioenerg. 975(3): 384-394.

Retief ECL, Stanger TK (2009) Genetic control of wood density and bark thickness, and their correlations with diameter, in pure and hybrid populations of Eucalyptus grandis and E. urophylla in South Africa. South Forests. 71(2): 147-153.

Ripullone F, Grassi G, Lauteri M, Borghetti M (2003) Photosynthesis-nitrogen relationships: interpretation of different patterns between Pseudotsuga menziesii and Populus $\times$ euroamericana in a mini-stand experiment. Tree Physiol. 23(2): 137-144.

Sands R, Nambiar ES (1984) Water relations of Pinus radiata in competition with weeds. Can $\mathrm{J}$ For Res. 14(2): 233-237.

Santos MV, Ferreira EA, Santos LDT, da Fonseca DM, Aspiazú I, Silva DV, Porto JM, Braga RR (2015) Physiological aspects of acacia and eucalyptus in competition with Brachiaria. Aust J Crop Sci. 9(3): 210- 214.

Schaller M, Schroth G, Beer J, Jiménez F( 2003) Root interactions between young Eucalyptus deglupta trees and competitive grass species in contour strips. For Ecol Manage. 179(1): 429-440.
Schreiner HG (1988) Viabilidade de um sistema silvipastoril em solos de areia quartzosa no Estado de São Paulo. Boletim de Pesquisa Florestal. 17: 33-38.

Silva W, Silva SA, Sediyama T, Freitas LHL (1997) Altura e diâmetro de Eucalyptus citriodora e E. grandis, submetidos a diferentes teores de água em convivência com Brachiaria brizantha. Floresta. 27(12): 3-16.

Stape JL, Binkley D, Ryan MG, Gomes AND (2004) Water use, water limitation, and water use efficiency in a Eucalyptus plantation. Bosque. 25(2): 35-41.

Tarouco CP, Agostinetto D, Panozzo LE, Santos LS, Vignolo GK, Ramos LOO (2009) Períodos de interferência de plantas daninhas na fase inicial de crescimento do eucalipto. Pesqui Agropecu Bras. 44(9): 1131-1137.

Toledo REB, Alves PLCA, Valle C, Alvarenga SF (1996) Comparação dos custos de quatro métodos de manejo de Brachiaria decumbens Stapf em área de implantação de Eucalyptus grandis W Hill ex Maiden. Rev Árvore. 20(3): 319-330.

Toledo REB, Victória Filho R, Alves PLCA, Pitelli RA, Cadini, MTD (2000) Efeitos da faixa de controle do capim-braquiária (Brachiaria decumbens) no desenvolvimento inicial de plantas de eucalipto. Planta Daninha. 18(3): 383-393

Toledo REB, Dinardo W, Bezutte AJ, Alves PLCA, Pitelli RA (2001) Efeito da densidade de plantas de Brachiaria decumbens Stapf sobre o crescimento inicial de mudas de Eucalyptus grandis W Hill ex Maiden. Sci For. 60(1): 109-117.

Watt MS, Whitehead D, Mason EG, Richardson B, Kimberley MO (2003) The influence of weed competition for light and water on growth and dry matter partitioning of young Pinus radiata, at a dryland site. For Ecol Manage. 183(1): 363-376. 